\title{
Astyanax cocibolca, a new characid (Pisces: Ostariophysi) from Lake Nicaragua, Central America
}

\author{
William A. Bussing \\ Escuela de Biología \& Centro de Investigaciones en Ciencias del Mar y Limnología (CIMAR), Universidad de Costa \\ Rica, San José, Costa Rica.
}

Received 19-IV-2007. Corrected 30-VI-2008. Accepted 09-VI-2008.

\begin{abstract}
Astyanax cocibolca, a small filter-feeding species is a new characid species endemic to Lake Nicaragua. It is distinguished from the syntopic Astyanax aeneus by its high gill raker count, slender body, upturned snout, long maxillary bones, conical outer premaxillary teeth, lower number of scales above lateral line, more intense black lateral band, smaller size, and trophic niche partitioning. At present the new species utilizes the open-water habitat at least as a nursery where young can feed on the rich plankton population. Adults feed on copepoda, cladocera, fruits, seeds and algae. The bulk of the adult population presumably resides inshore. Rev. Biol. Trop. 56 (3): 1361-1370. Epub 2008 September 30.
\end{abstract}

Key words: Astyanax, new characid fish, Lake Nicaragua, plankton feeder.

Eigenmann and Ogle (1907) wrote "In the difficult and highly interesting group of characins there is no more difficult nor more interesting genus than Astyanax." They further noted that a widely variable group of related species in Central America and Mexico, centering upon Astyanax rutilus, would require much larger series to determine their status.

Now, 100 years later, little has changed in Middle American Astyanax taxonomy. Astyanax rutilus (=aeneus) and $A$. mexicanus still present a mosaic of difficult-to-define local geographic populations in Mexico and Central America. Several of these local forms have been recognized as distinct species especially if shown to be sympatric with another Astyanax species (Schmitter Soto 1998). Some distinctive populations with reduced or restricted distributions also merit recognition (Lozano-Vilano and ContrerasBalderas 1990). The subject of the present study is a presumptive case of sympatric speciation of a semipelagial species in Lake Nicaragua. Spatial and trophic niche partitioning between the new species and the syntopic $A$. aeneus is indicated.
Astorqui (1972, 1975), based on collections made in the Nicaraguan Lakes basin in 1960, proposed that two species of Astyanax were syntopic in the basin, but did not formally describe the new form. In 1971 biologists from the Fisheries Division of the Instituto de Fomento Nacional (INFONAC) in collaboration with FAO/UN, U.S. Peace Corp and investigators from several universities initiated a three-year study to evolve a rational plan for the development and management of the Lake's fishery resources (INFONAC 1974, Davies 1976). On the initial cruises of the Program on the $\mathrm{M} / \mathrm{N}$ Gaspar, I was able to capture fishes from throughout the lake and at diverse shore localities. This and other material collected by Jaime Villa in 1966 and 1968 provided the specimens of Astyanax for this study.

\section{MATERIAL AND METHODS}

A variety of seines were used to collect at inshore sites, along beaches and around the Isletas of Granada. A few small individuals of 
A. cocibolca and other small species were taken incidentally while trawling in offshore waters for cichlids and other commercially important fishes. In order to sample juveniles and small species, a fine-mesh net was placed in the cod end of the try net on several attempts. This produced 60 specimens of juvenile and young adults of the cocibolca sardine (UCR 539-6) and other smaller catches.

Counts and measurements follow the methods given in Fink and Weitzman (1974). An additional measurement is Maxillary Length which refers to that portion of the bone extending from the rictus of the upper jaw to distalmost termination of the maxillary bone. Sex was determined by dissection. Body measurements are given in $\mathrm{mm}$ standard length (SL). All proportional measurements are in percentages of SL. Vertebral counts were determined from cleared and alizarinstained specimens. The holotype is deposited in the Natural History Museum of Los Angles County (LACM); paratypes are deposited in LACM, Museu de Ciencias e Tecnologia, Porto Alegre, Brazil (MCP) and American Museum of Natural History (AMNH); other paratypes and all comparative material is deposited in the Museo de Zoología, Universidad de Costa Rica (UCR).

\section{RESULTS}

Astyanax cocibolca, new species Figure 1, 3; Tables 1-5

Astyanax nasutus (non Meek 1907) Bussing 1976:160; Villa 1982:102; Bussing 1987:70; Bussing 1998:85.

Astyanax sp. (nasutus?) Villa 1976:192.

Astyanax sp. Astorqui 1972:22; Astorqui 1975:80; Lucena and Lucena 2002:116.

Holotype. LACM 56648-1, male, 44.2 $\mathrm{mm}$, Isletas de Granada, Lake of Nicaragua, elevation $31 \mathrm{~m}$, depth $1.5 \mathrm{~m}$, April 6-10, 1966, J.D. Villa \& M. Llobet (exUCR 24-16).

Paratypes. (All material from Lake Nicaragua, Nicaragua except where noted) LACM 56648-2, 50, 27.5-46.5 mm; MCP 28714, 20, -- mm; AMNH 30236, 20, -- mm; UCR 24-16, 924, 27.8-53.6 mm, same locality

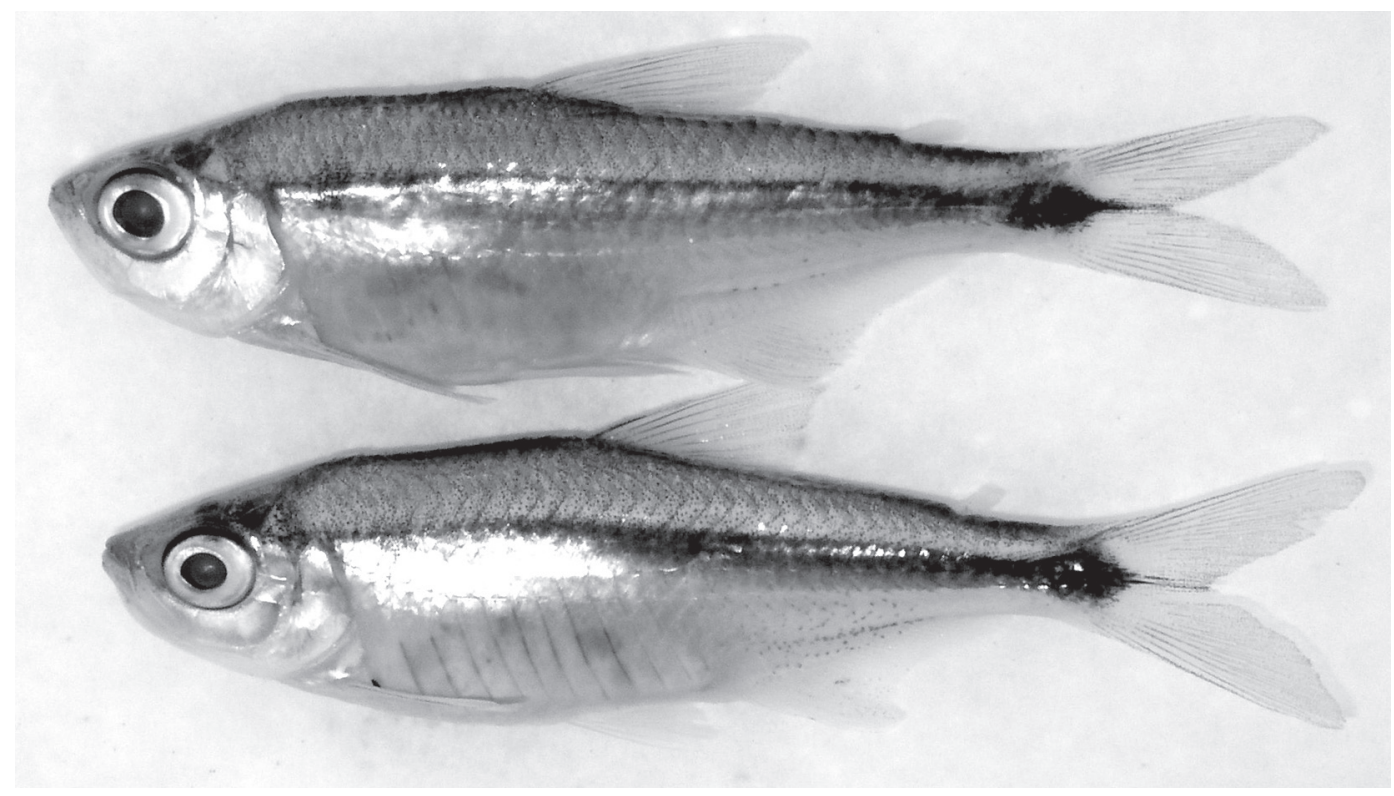

Fig. 1. Astyanax cocibolca, n. sp., LACM 56648-1, male holotype, $44.2 \mathrm{~mm}$ (upper) and UCR 24-16, female paratype, 46.2 $\mathrm{mm}$, Lake of Nicaragua. 
and data as holotype. UCR 61-4, 301, 31.4$51.0 \mathrm{~mm}$, Puerto de Asese, Granada, $21 \mathrm{Jul}$ 1966. UCR 62-2, 238, 33.4-55.3 mm, Isletas of Granada, 21 Jul 1966. UCR 242-7, 4, 31.2$49.0 \mathrm{~mm}$, Isletas of Granada, 9-10 Apr 1968. UCR 536-8, 42, 34.3-50.0 mm, beach in front of INFONAC laboratory, Granada, 23-24 Nov 1971. UCR 538-6, 3, 19.6-31.3, 6 km NNE Granada, $5 \mathrm{~km}$ from shore, 25 Nov 1971. UCR 539-6, 60, 16.9-40.2 mm, 10 km NNE Granada and $8 \mathrm{~km} \mathrm{~S}$ El Porvenir, 5-7 km from shore, 25 Nov 1971. UCR 540-5, 3, 28.2-38.0 mm, $5 \mathrm{~km}$ $\mathrm{S}$ of mouth of River Estrella, $4 \mathrm{~km}$ from shore, 26 Nov 1971. UCR 542-8, 3, 35.6-42.3 mm, off Estero El Junquillo, 1-7 km from shore, 28 Nov 1971. UCR 547-6, 1, $40.2 \mathrm{~mm}$, beach at Estero El Guayabo, 25 Nov 1971. UCR 552-3, 1, 40.7 $\mathrm{mm}$, beach W of mouth of River Cacaguapa, 27 Nov 1971. UCR 553-2, 1, 35.5 mm, beach W of mouth of River Mayales, Punta Mayales, 28 Nov 1971.

Costa Rica. - UCR 1061-4, 2, 39.5-53.1 mm, sand banks in River San Juan, off mouth of River San Carlos, Costa Rica, 8 Jan 1977. UCR 1075-8, 3, -- mm, "El Hueco", River
Colorado, 2 km SW Barra Colorado, Costa Rica, 6 Nov 1976.

Diagnosis. Freshly collected and preserved specimens of $A$. cocibolca can be readily separated from the syntopic $A$. aeneus that inhabits some of the same habitats in Lake Nicaragua. The new species is semipelagial and can be distinguished from the sympatric lacustrine A. aeneus by its slenofr body $(29.1-36.4 \%$ vs $33.9-39.3 \% \mathrm{SL}$ ); the slightly upturned mouth; high total gill raker count (23-34, mean 28.9 vs $22-26$, mean 24.1 ; reduced size of dentary teeth; fewer scale rows above lateral line (6-8, mean 7.2 vs $8-9$, mean 8.3 ); more intense black midlateral band; smaller size (maximum 54.3 vs $>80 \mathrm{~mm} \mathrm{SL}$ ); and conical teeth in outer row of premaxillary bone (only tricuspid outer row teeth were found in A. aeneus from four Costa Rican regions, and sites in Belize, Guatemala and Panama).

Description. Table 1 gives morphometrics of the holotype, 50 adult paratypes and respective data for 30 adult Astyanax aeneus

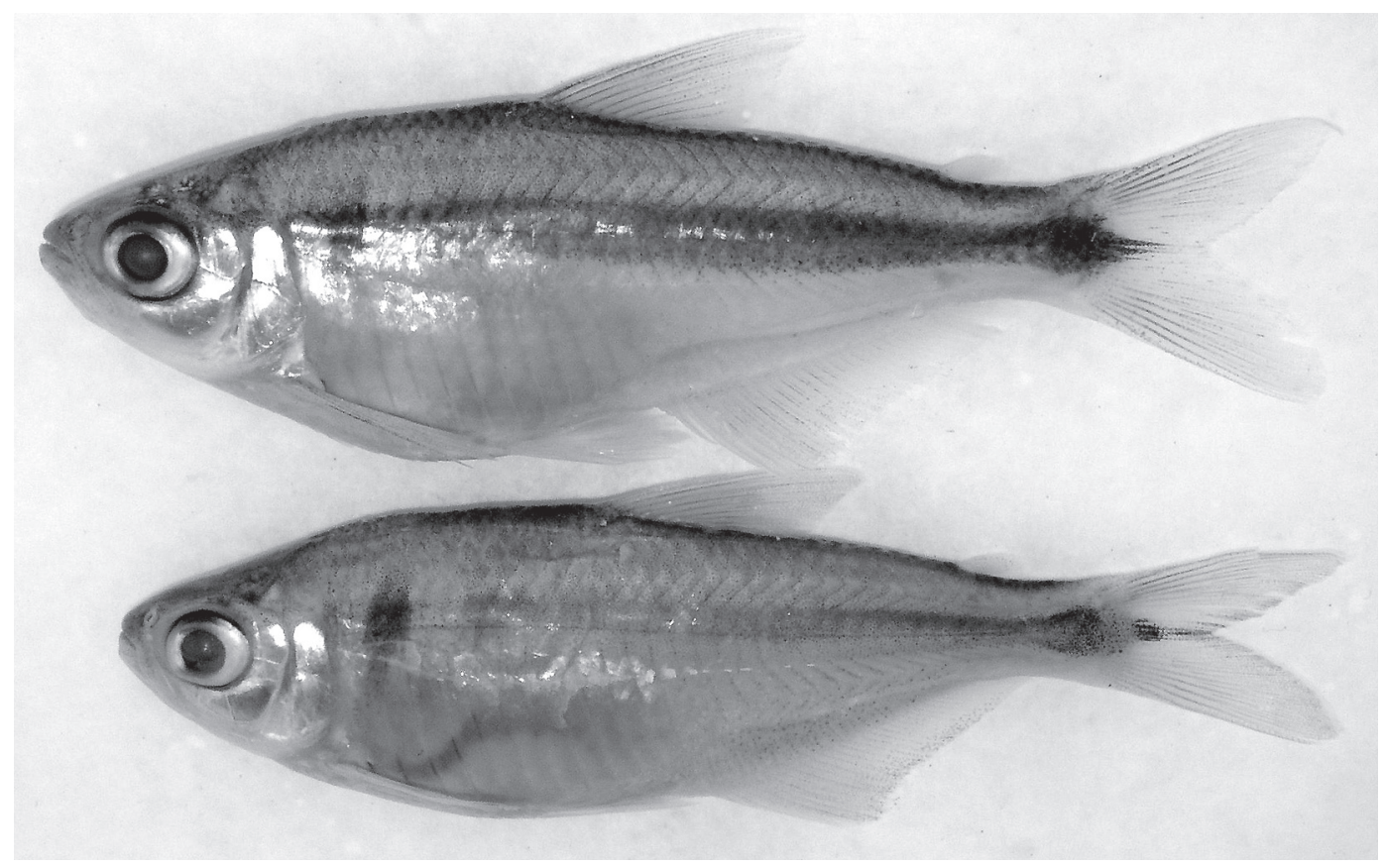

Fig. 2. Astyanax aeneus, UCR 63-1, female, $56.2 \mathrm{~mm}$ (upper) and UCR 24-8, male $56.4 \mathrm{~mm}$, Lake de Nicaragua. 
TABLE 1

Body proportions for type specimens of Astyanax cocibolca $n$. sp. and Lake Nicaragua Astyanax aeneus in percent of standard length

\begin{tabular}{|c|c|}
\hline Measurement & Holotyl \\
\hline Standard length (mm) & 44.2 \\
\hline Head length & 29.4 \\
\hline Eye diameter & 10.9 \\
\hline Snout length & 7.0 \\
\hline Maxillary length & 7.9 \\
\hline Interorbital width & 7.7 \\
\hline Greatest body depth & 32.8 \\
\hline Caudal peduncle depth & 11.3 \\
\hline Caudal peduncle length & 13.6 \\
\hline Snout to dorsal-fin origin & 51.4 \\
\hline Snout to anal-fin origin & 63.8 \\
\hline Snout to pectoral-fin origin & 27.8 \\
\hline Snout to pelvic-fin origin & 49,1 \\
\hline Length $1^{\text {st }}$ dorsal-fin ray & 27.8 \\
\hline Length $1^{\text {st }}$ anal-fin ray & 14.5 \\
\hline Length $1^{\text {st }}$ pectoral-fin ray & 24.4 \\
\hline Length $1^{\text {st }}$ pelvic-fin ray & 19.9 \\
\hline \multicolumn{2}{|c|}{$\begin{array}{l}\text { from Lake Nicaragua. Astyanax cocibolca is } \\
\text { a small slender-bodied species of the genus. } \\
\text { Predorsal profile convex; straight over nape, } \\
\text { nape to origin of dorsal fin straight or slightly } \\
\text { rounded. Dorsal profile of body along dorsal-fin } \\
\text { base straight. Mouth superior, lower jaw project- } \\
\text { ing slightly in advance of tip of snout giving an } \\
\text { upturned appearance to ventral margin of head. } \\
\text { Greatest body depth between origin of dorsal fin } \\
\text { and midpelvic fins; only a small overlap with the }\end{array}$} \\
\hline
\end{tabular}

Astyanax cocibolca

$\begin{array}{cc}\text { Holotype } & \text { Paratypes (50) } \\ 44.2 & 39.5-54.3 \\ 29.4 & 27.0-30.0 \\ 10.9 & 8.2-11.0 \\ 7.0 & 5.9-8.3 \\ 7.9 & 7.0-9.3 \\ 7.7 & 6.0-9.1 \\ 32.8 & 29.1-36.4 \\ 11.3 & 10.0-12.8 \\ 13.6 & 10.9-15.4 \\ 51.4 & 47.9-52.9 \\ 63.8 & 63.4-68.6 \\ 27.8 & 26.0-31.1 \\ 49,1 & 46.1-50.9 \\ 27.8 & 23.7-28.6 \\ 14.5 & 15.6-19.5 \\ 24.4 & 18.6-23.0 \\ 19.9 & 13.6-18.2\end{array}$

Astyanax aeneus

$43.8-79.2$

$25.0-30.8$

7.8-10.3

$5.8-8.1$

5.8-7.9

7.9-9.7

$33.9-39.2$

11.0-13.5

11.1-13.9

49.4-54.4

62.4-69.7

24.3-29.2

45.6-49.4

24.6-29.4

15.3-20.2

19.7-23.6

$13.9-18.8$

deeper-bodied $A$. aeneus (Table 2 and Fig. 2). No evidence of sexual dimorphism was found in meristics or morphometrics.

Fin rays (number of counts in parentheses; holotype counts in bold font): dorsal ii8 (2) or ii9 (50); anal usually with 3 or 4 unbranched rays before branched 22 (9), 23 (33), 24 (57), 25 (32), 26 (10), 27 (1), mean 24.0; pectoral 1 or 2 unbranched rays before branched 10 (4), 11 (15), 12 (27), 13 (4), 14 (2), mean 11.7;

TABLE 2

Frequency distribution of greatest body depth of Astyanax cocibolca and Astyanax aeneus in percent of standard length

\begin{tabular}{lllllllllllll}
\multicolumn{10}{c}{ Class Intervals } \\
29.0 & 30.0 & 31.0 & 32.0 & 33.0 & 34.0 & 35.0 & 36.0 & 37.0 & 38.0 & 39.0 & 40.0 & 41.0 \\
29.9 & 30.9 & 31.9 & 32.9 & 33.9 & 34.9 & 35.9 & 35.9 & 37.9 & 38.9 & 39.9 & 40.9 & 41.9
\end{tabular}

$\begin{array}{lllllll}\text { A. cocibolca } & 2 & 6 & 16 & 10 & 8 & 8\end{array}$

A. aeneus

3

219

$10 \quad 1 \quad 1$ 
pelvic I 7 (51); caudal 17 branched rays (51). Total gill rakers: 23-34, mean 28.9 (Table 3). Scales: lateral series, 34 (5), 35 (10), 36 (24), 37 (8), 38 (4), mean 35.9; rows above lateral series, 6 (2), 7 (37), 8 (11), mean 7.2 (Table 4); predorsal, 10 (4), 11 (24), 12 (15), 13 (3), mean 11.4; around caudal peduncle, 13 (2), 14 (12), 15 (16), 16 (6), mean 14.7. Total vertebrae including four elements of Weberian apparatus: 35 (8), 36 (6).

Ventral extension of maxillary bone longer than in A. aeneus; note serrations on some large males of A. cocibolca and aeneus (Table 5, fig. 3 and fig. 4). Maxillary teeth 1 to 4, mean 2.1 teeth (Table 6); teeth very small, compressed, with 2 to 5 rounded cusps, central cusp not pronounced, holotype with 1-2 maxillary teeth. Premaxillary teeth in two series: Inner series with 4 (42), 5 (45), 6 (11), mean 4.7 teeth. Teeth ovoid in cross section; symphysal teeth broad with prominent central cusp flanked by two pairs of smaller cusps; teeth decreasing in size and number of cusps laterally. Outer series unevenly distributed, teeth conical, long, and

TABLE 3

Frequency distribution of the number of total gill rakers in Astyanax cocibolca $n$. sp. and Astyanax aeneus

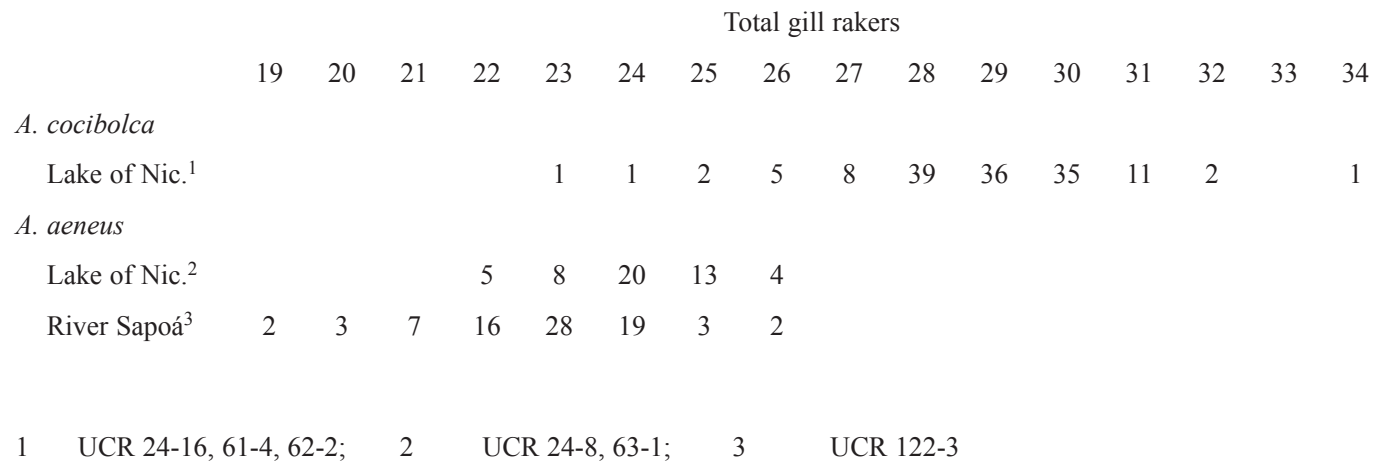

TABLE 4

Frequency distribution of the number of scale rows above the lateral line in Astyanax cocibolca $n . s p$. and Astyanax aeneus Scales above lateral line

$\begin{array}{lcccc} & 6 & 7 & 8 & 9 \\ \text { A. cocibolca } & 2 & 37 & 11 & 17 \\ \text { A. aeneus } & & & 33\end{array}$

TABLE 5

Frequency distribution of maxillary length of Astyanax cocibolca and Astyanax aeneus in percent of standard length

\begin{tabular}{lcccccccc} 
& \multicolumn{7}{c}{ Class Intervals } \\
& 6.0 & 6.5 & 7.0 & 7.5 & 8.0 & 8.5 & 9.0 & 9.5 \\
& 6.4 & 6.9 & 7.4 & 7.9 & 8.4 & 8.9 & 9.4 & 9.9 \\
A. cocibolca & 1 & 1 & 16 & 25 & 6 & 9 & 9 & 1 \\
A. aeneus & 1 & & & & & & &
\end{tabular}


TABLE 6

Frequency distribution of the number of maxillary teeth in Astyanax cocibolca $n$. sp. and Astyanax aeneus

Maxillary teeth
2

3

4

5

6

8

9

\section{A. cocibolca}

Lake of Nic.

51

21

6

\section{A. aeneus}

Lake of Nic.

River Sapoá

$$
13
$$

59

59

23

18

17
11

15

5

5

3
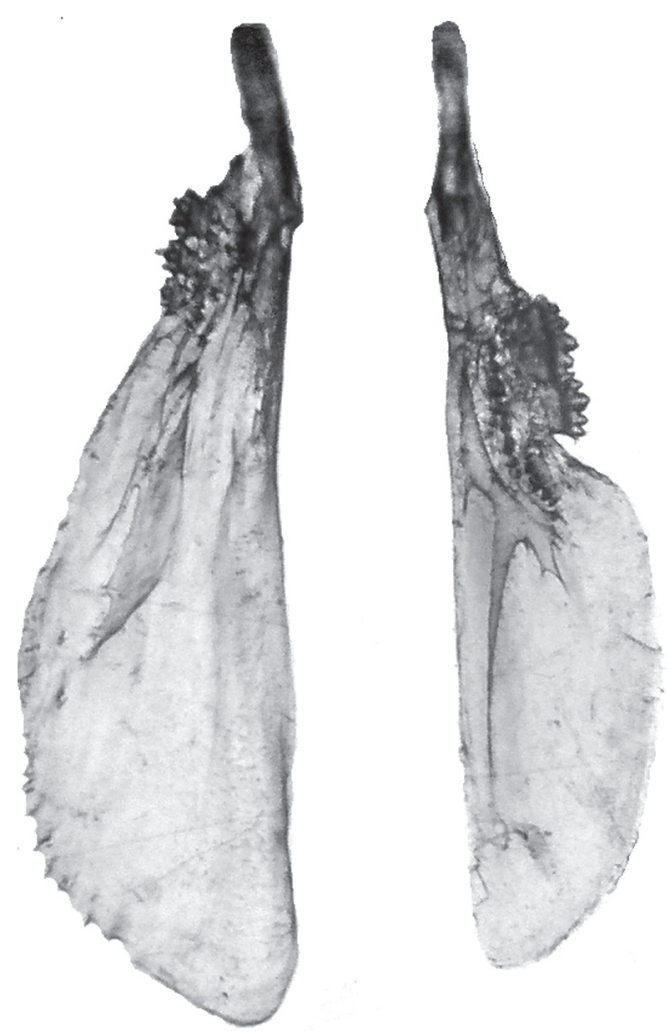

Fig. 3. Maxillary bones of Astyanax cocibolca, n.sp. UCR 62-2, female $47.9 \mathrm{~mm}$, left maxilla (5.0 mm long); UCR 24-16, male $48.0 \mathrm{~mm}$, right maxilla (5.0 mm long); Lake of Nicaragua.
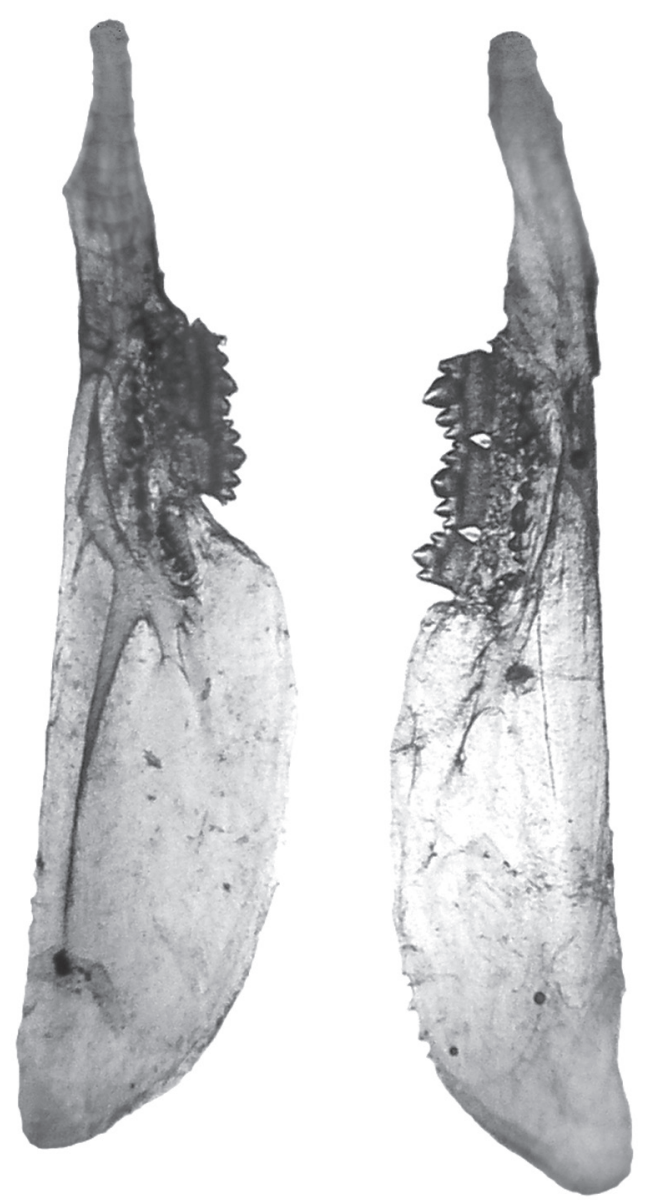

Fig. 4. Maxillary bones of Astyanax aeneus. UCR 1223, female $45.9 \mathrm{~mm}$, left maxilla (4.1 mm long). River Sapoá, tributary of Lake de Nicaragua. UCR 546-8, male $46.0 \mathrm{~mm}$, right maxilla (4.7 $\mathrm{mm}$ long); Tipitapa, Lake of Nicaragua. 
round or oval in cross section, no cusps except minute cusps on largest specimen, 0 (5), 1 (21), 2 (34), 3 (18), 4 (9), 5 (1), mean 2.2 teeth. Dentary teeth similar to inner premaxillary, symphysal teeth large with prominent central cusp flanked by two pairs of smaller cusps, 3 (2), 4 (53), 5 (36), 6 (3), mean 4.4 teeth. Laterally 4 to 7 small teeth decreasing in size and number of cusps (5 to 1 cusps).

Live coloration of head and body is bright silvery; an underlying black midlateral band is notable only on the caudal peduncle and base of caudal fin, extending to the tips of the midcaudal rays. Coloration in alcohol is dependant on the duration in formalin which affects the silvery guanine pigment. Beneath the guanine layer the fish are tan above, pale straw color below; a black midlateral band of eye width extends between the upper margin of the opercle to tail base, forming a large caudal spot and continuing as a narrow stripe to the end of the middle rays. A diffuse humeral blotch extends slightly above the lateral band.

Ecology. Thirty-two species of freshwater fishes are found in the Great Lakes proper; fourteen other freshwater species have been collected in affluents to the lakes or tributaries of the River San Juan. The lake covers an area of $8,264 \mathrm{~km}^{2}$, the longest axis $160 \mathrm{~km}$; maximum depth is about $70 \mathrm{~m}$, average only 9-13 m (Incer 1973). Oxygen values of surface waters of $74-173 \%$ saturation imply intense photosynthesis (Cole 1976). The shallow depth and abundance of phyto- and zooplankton suggest very high productivity throughout this tropical lake.

Planktivorous fishes inhabiting Lake Nicaragua include the shad Dorosoma chavesi and the silverside Atherinella sardina. Although some Dorosoma were collected in open waters, A. sardina was taken only in shallow inshore habitats around the lake. Thus, the relatively empty small-planktivore niche apparently allowed $A$. aeneus to evolve a filter-feeding specialist, A. cocibolca. At present the new species utilizes the open-water habitat at least as a nursery where young can feed on the rich plankton population. Two small adults from the open water habitat contained $90 \%$ copepoda and cladocera. The bulk of the adult population presumably resides inshore where it can gorge opportunistically on plant and other food matter. Inshore specimens contained $90 \%$ fruit, 5\% cladocera, 5\% seed, algae. Twelve A. aeneus from inshore sites contained $90 \%$ fruit, husks, etc., $10 \%$ chironomid larvae and terrestrial insects. Thus, there is partial trophic niche partitioning between these two syntopic Astyanax species. The adult A.cocibolca female from open water contained ripe eggs, although ten adult females from inshore sites contained only undeveloped eggs. Only one of nine adult A.aeneus showed any egg development. Observations made in the lake during other times of the year presumably would produce different results.

Etymology. The species is named for Lake Cocibolca, the indigenous name for Lake Nicaragua. The name is used as a noun in apposition.

\section{DISCUSSION AND RELATIONSHIPS}

Eigenmann (1921) considered Astyanax rutilus a synonym of Astyanax fasciatus, both species originally described from Brazil. He included five subspecies in fasciatus, one being A. fasciatus aeneus (Günther 1860) originally described from Oaxaca, Mexico and recently considered part of the "Astyanax fasciatus species complex" by Melo and Buckup (2006). In describing the new species Astyanax armandoi, Lozano-Vilano and Contreras-Balderas (1990) reviewed the state of the taxonomy of Astyanax in Mexico. They tentatively recognize two wide-ranging species: Astyanax mexicanus in northern Mexico and Astyanax aeneus southward from River Papaloapan and Oaxaca into Central America.

Eigenmann (1921) included Astyanax oerstedii (Lütken 1874), described from River San Juan (the effluent of Lakes Managua and Nicaragua), as a synonym of $A$. fasciatus; but he recognized as valid species $A$. nicaraguensis 
(Eigenmann and Ogle 1907) from "Nicaragua" and Deuterodon nasutus (Meek 1907) from Lake Managua, Nicaragua. Regarding A. nicaraguensis, Eigenmann stated "In general characters the specimens agree with the specimens of $A$. aeneus, and those with but two maxillary teeth are indistinguishable from them. The fact that such a large per cent of specimens have a large number of maxillary teeth entitles them to a separate name." He thought it possible that specimens with numerous maxillary teeth are all males, although this is not the case. Bussing (1998) considered this Lake Nicaragua population a case of speciation in progress whereby numerous maxillary teeth provide some advantage to this lacustrine population of $A$. aeneus. Typical Central American aeneus have 1-3 maxillary teeth, usually 2 , but in tributaries of Lake Nicaragua such as River Sapoá they usually have 1-5 teeth, average 2.9 compared with $1-9$, average 4.5 in the lake specimens (Table 6). This suggests that the lacustrine aeneus are not a closed gene pool, and some selective pressure maintains a high tooth count in spite of intergrading with fluviatile populations. A large number of maxillary teeth may improve capability of capturing more active and larger prey organisms. The sympatric Bramocharax bransfordi with 6-19 maxillary teeth and long snout (Rosen 1970) is a formidable predator. Eighteen $B$. bransfordi from the River Puerto Viejo, a Costa Rican tributary of the River San Juan, ate $51 \%$ fish, the remainder mostly insects (Bussing 1993).

Meek (1907) described Astyanax nasutus from Lake Managua and A. aeneus from both Lake Managua and Nicaragua. A comparison of the two species descriptions reveals very little difference: a longer snout and maxillary, a concave profile between nape and end of snout, larger size, and a prominent chin in nasutus. Eigenmann (1921) redescribed three paratypes of nasutus of about $104 \mathrm{~mm}$ and included a fine drawing of one of the specimens. Although he stated the stomach was filled with plants, the species is a very large and formidable-looking Astyanax. He placed nasutus in the genus Deuterodon based principally on the teeth of the lower jaw being regularly graduate from in front to the last tooth on the sides as opposed to Astyanax with teeth of the sides of the lower jaw more or less abruptly minute. He also noted a greater head length than that given by Meek (27.7-29.7\% vs $23.3-25.6 \%$ SL). I examined two (80.7 and $81.8 \mathrm{~mm}$ ) paratypes of nasutus (IU11600), and also found greater head length than typical Lake aeneus (29.629.8 vs $24.9-25.5 \%$ SL). Lucena and Lucena (2002) redefined the genus Deuterodon, and on the basis of three synapomorphies, recognized seven species, all from South America. These synapomorphies of the maxillary bone exclude the nominal $D$. nasutus, which they considered incertae sedis. Upon request from the Lucenas in 2001, I donated material of what I had considered A. nasutus (UCR 24-16). They determined that the specimens were not a Deuterodon, nor representative of the species nasutus, and considered it an Astyanax sp. A more careful analysis of a large series of this material and the literature bear out their conclusions and resulted in the present study of the previously undescribed Astyanax cocibolca.

Astorqui $(1972,1975)$ reported on a large collection that he and L.R. Rivas made in 1960 in the Great Lakes basin (Lakes Managua and Nicaragua). He concluded there were two valid species of Astyanax in the basin: A. fasciatus (including as synonyms aeneus, nicaraguensis and nasutus) and Astyanax sp. The latter was distinguished from fasciatus by its slender body, upturned snout, and very dark lateral band with diffuse humeral spot when preserved. Astorqui's recognition that Astyanax sp. was not assignable to any known species was correct and not adequately recognized in subsequent studies of Nicaraguan fishes.

No specimens of $A$. nasutus have been reported since the original description of 12 specimens from Lake Managua and one specimen from Cisplaya, a small nearby lake. The fact that nasutus was found only in Lake Managua and the nicaraguensis-type aeneus and cocibolca are known only from Lake Nicaragua support other faunal evidence that River Tipitapa connecting the two lakes is a 
virtual barrier to free passage due to a sandstone dropoff, hot springs and lack of running water (Villa 1976). Since sometime in the past, waters rarely flow through the Tipitapa which at present is a slow-moving swamp filled with water hyacinth Eichornia azurea (Incer 1973,1976). This isolation has permitted the Lake Managua nasutus to diverge in dentary and other traits. Astyanax nasutus was reported to have 4 to 6 maxillary teeth, but I counted 7-8 maxillary teeth on one of the two paratypes I examined. Thus, like A. aeneus in Lake Nicaragua, it has an increased number of maxillary teeth and modified lower jaw dentition as well. Regrettably Astorqui did not obtain nasutus while collecting at Lake Managua, as I believe he would have distinguished it as distinct from aeneus from the same lake.

Comparative Material: Astyanax aeneus was collected together with $A$. cocibolca at six stations: UCR 24-8, 58, 31.0-78.6 mm; UCR 242-6, 1, 46.6 mm; UCR 536-7, 22, 21.8-50.8 mm; UCR 547-4, 39, 21.4-74.5 mm; UCR 5522, 52, 23.8-48.9 mm; UCR 553-1, 45, 20.8-45.2 $\mathrm{mm}$. Astyanax aeneus was also collected at the following Lake Nicaragua stations where no A. cocibolca were present: UCR 63-1, 7, 41.5$62.5 \mathrm{~mm}$, Isletas de Granada, 20 Jun 1966. UCR 546-8, 71, 23.2-70.0 mm, shore mouth of River Tipitapa, 25 Nov 1971. UCR 548-3, 44, 17.3-31.4 mm, shore at Bahía La Pelona, 26 Nov 1971.

\section{ACKNOWLEDGMENTS}

I am grateful to R. Camacho of the Ministry of Agriculture and the biologists of INFONAC, Nicaragua; to the FAO/UN fisheries biologists R. Ellis, S. Lofnes and A. Hagberg who designed the fisheries resources program; to C.A.S. and Z.M.S. Lucena for bringing to my attention that specimens of $A$. cocibolca were not A. nasutus; to A. Arostegui, R. Beatty, K. Koenig, L. Reyes and J. Villa who collaborated in the collection of specimens. Special thanks go to I. Astorqui, S.J. for recognizing Astyanax cocibolca as an undescribed species early on.

\section{RESUMEN}

Se describe Astyanax cocibolca, una nueva especie pequeña y planctívora, endémica en el Lago de Nicaragua. Se distingue de la especie simpátrica Astyanax aeneus por su alto número de branquiespinas, cuerpo delgado, hocico inclinado hacia arriba, maxilar serrado en algunos, dientes unicúspides en la fila exterior del premaxilar, menor número de escamas arriba de la línea lateral, banda negra lateral más intensa y tamaño menor.

Palabras clave: Astyanax, nuevo pez carácido, Lago Nicaragua, especie planctívora

\section{REFERENCES}

Astorqui, I. 1972. Peces de la cuenca de los grandes Lagos de Nicargua. Rev. Biol. Trop. 19:7-57.

Astorqui, I. 1975. Peces de la cuenca de los grandes Lagos de Nicargua. Publicaciones Nicaragüense, Managua. $179 \mathrm{p}$.

Bussing, W.A. 1976. Geographic distribution of the San Juan ichthyofauna of Central America with remarks on its origin and ecology. In: T.B. Thorson (ed.) Investigations of the ichthyofauna of Nicaraguan Lakes. University of Nebraska, Lincoln, Nebraska, USA. $157-175$ p.

Bussing, W.A. 1993. Fish communities and environmental characteristics of a tropical rain forest river in Costa Rica. Rev. Biol. Trop. 41:791-809.

Bussing, W.A. 1998. Peces de las aguas continentales de Costa Rica. University of Costa Rica, San Pedro, Costa Rica. 468 p.

Cole, G.A. 1976. Limnology of the Great Lakes of Nicaragua. In: T.B. Thorson (ed.) Investigations of the ichthyofauna of Nicaraguan Lakes. University of Nebraska, Lincoln, Nebraska, USA. 9-15 p.

Davies, W.D. 1976. Lake Nicaragua fishery resources. In: T.B. Thorson (ed.) Investigations of the ichthyofauna of Nicaraguan Lakes. University of Nebraska, Lincoln, Nebraska, USA. 261-265 p.

Eigenmann, C.H. \& F. Ogle. 1907. An annotated list of characin fishes in the United States National Museum and the Museum of Indiana University, with descriptions of new species. Proc. U.S. nat. Mus. 33:1-36.

Eigenmann, C.H. 1921. The American Characidae. Mem. Mus. Comp. Zool. 43: 209-310.

Fink, W.L., and S.H. Weitzman. 1974. The so-called Cheirodontin fishes of Central America with descrip- 
tions of two new species (Pisces: Characidae). Smiths. Contr. Zool. 172: 1-46.

Hagberg, A.H. 1968. Informe sobre las investigaciones preliminaries en el Lake de Nicaragua (28/8 al 17/9/1968. Proy. Reg. Desarrollo Pesq. Centro America, FAO/ UN, Circ. 68/39: 1-14.

Incer, J. 1973. Geografía ilustrada de Nicaragua. Librería y Editorial Recalde, S. A., Managua, Nicaragua. 255 p.

Incer, J. 1976. Geography of lake Nicaragua. In: T.B. Thorson (ed.) Investigations of the ichthyofauna of Nicaraguan Lakes. University of Nebraska, Lincoln, Nebraska. USA. 3-7 p.

INFONAC. 1974. Informe sobre los resultados del programa de investigación de los recursos pesqueros del Lago de Nicaragua. División de Pesca, Managua, Nicaragua. $44 \mathrm{p}$.

Lozano Vilano, M.L. \& S. Contreras Balderas 1990. Astyanax armandoi, n. sp. from Chiapas, Mexico (Pisces, Ostariophysi: Characidae) with a comparison to the nominal species A. aeneus and A. mexicanus. Universidad y Ciencia (Managua) 7: 95-107.

Lucena, C.A.S. \& Z.M.S. Lucena 2002. Dedefinicao do genero Deuterodon Eigenmann (Ostariophysi: Characiformes: Characidae). Comun. Mus. Cienc. Tecnol. PUCRS, Ser. Zool. 15: 113-135.
Melo, F.A.G. \& P.A. Buckup 2006. Astyanax henseli, a new name for Tetragonopterus aeneus Hensel, 1870 from southern Brazil (Teleostei: Characiformes). Neotrop Ichthyol 4: 45-52.

Meek, S.E. 1907. Synopsis of the fishes of the Great Lakes of Nicaragua. Field Columbian Mus., Zool. Ser., 5: $1-252$.

Rosen, D.E. 1970. A new tetragonopterine characid fish from Guatemala. Amer. Mus. Novitates 2435:1-17.

Schmitter Soto, J.J. 1998. Diagnosis of Astyanax altior (Characidae), with a morphometric analysis of Astyanax in the Yucatan Peninsula. Ichthyol Explor Fres 8: 349-358.

Thorson, T.B. 1976. Investigations of the ichthyofauna of Nicaraguan Lakes. (Editor). University of Nebraska, Lincoln, Nebraska, USA. 663 p.

Villa, J. 1976. Some speculations about "The Great Nicaraguan Lake". In T.B. Thorson (ed.) Investigations of the ichthyofauna of Nicaraguan Lakes. University of Nebraska, Lincoln, Nebraska, USA. 191-196 p.

Villa, J. 1982. Peces nicaraguenses de agua dulce. Editorial Unión Cardoaz y Cía. Ltda. Managua, Nicaragua. $253 \mathrm{p}$. 